\title{
Environmental Impacts of Desalination Activities in the Arabian Gulf
}

\author{
Saif Uddin
}

\begin{abstract}
Most of the power and freshwater needs in the Middle East are met by the desalination of seawater. With approximately 11 million $\mathrm{m}^{3}$ of freshwater being produced each day, the salinity of the seawater along the Gulf coast is increasing. This increase in salinity combined with higher sea surface temperatures is a big environmental challenge. However, continuous monitoring has highlighted that the acidifying Gulf water is utilizing this increased salinity to balance the $\mathrm{pH}$, thus saving detrimental effect on the ecology of the region. The effect of desalination is more severe on receptors including corals, and fisheries. Elevated levels of strontium have been measured in the Gulf as a result of its hypersalinity.
\end{abstract}

Index Terms -Strontium, hyper salinity, corals, fisheries.

\section{INTRODUCTION}

With extremely low and unreliable precipitation [1], desalination is the main source of freshwater in Middle East. The cumulative desalination capacity of the countries in the Arabian Gulf is around 11 million cubic meters (MCM) per day [2] including Kuwait, Saudi Arabia, Bahrain, Qatar, the United Arab Emirates and Iran is approximately $11 \mathrm{MCM}$ constituting some $45 \%$ of the total desalination activity of the world [2]. The main producers of desalinated water in Arabian Gulf are United Arab Emirates with a combined daily capacity in excess of $6.278 \mathrm{MCM} / \mathrm{d}$, Saudi Arabia 2.318 MCM/d, Kuwait 1.69 MCM/d, Qatar 0.917 MCM/d, Bahrain $0.358 \mathrm{MCM} / \mathrm{d}$ and Iran $0.205 \mathrm{MCM} / \mathrm{d}$ [3].

The uptake water used in desalination is critical. The situation varies throughout the Persian/Arabian Gulf. In Kuwait, water from the north is heavily impacted by the transboundary transport of suspended particulate [4] and extremely shallow bathymetry [5], both of which have a direct effect on desalination activities. Hence, enormous desalination facilities have been installed in the shallower depths on the western margin of Kuwait's waters. In this paper the salinity variations due to desalination are reviewed as increases in salinity can disturb the ecological balance and jeopardize the integrity of the local environment. The environmental impact of seawater desalination has been studied by Lattemann and Hopner [2] and Al-Barwani and Purnama [6] but those studies did not address the salinity variations that are spatially localized but environmentally critical.

Manuscript received July 26, 2013; revised September 22, 2013. This work was supported in part by the Kuwait Foundation for Advancement of Sciences under grant EM042C.

S. Uddin is with the Kuwait Institute for Scientific Research, Safat, 13109, KUWAIT (e-mail: sdin@kisr.edu.kw).

\section{MATERIALS AND METHODS}

\section{A. Environment Impact of Power and Desalination Plants}

An environmental impact assessment (EIA) for a desalination plant takes into consideration an exhaustive list of parameters. The potential impact of desalination activity includes impingement and entrainment of biota; emission of air pollutants; changes in marine water-quality especially salinity and temperatures; and the chemical discharges including biocides and chlorination, and biofouling and descaling chemicals used in the process [2], [7]-[10]. Most of the desalination plants in the northern Persian/Arabian Gulf are combined with power generation facilities. Thus, the environmental implications of desalination cannot be considered in isolation. An EIA in cases such as those in the Gulf should consider both power and desalination activities combined. The cogeneration plants are energy-efficient, using a single energy source to fuel two processes: propelling the power generation turbines (high-temperature steam) and water generation (low temperature steam that comes out of the turbine at about $120^{\circ} \mathrm{C}$ ). The air quality emissions, intake and outfall of a power and desalination facility are critical aspects on EIA.

\section{B. Environmental Impacts of Increased Salinity Due to Outfalls}

Brine discharge into sea poses an environmental challenge. With continuous discharge from power and desalination outfall equivalent water with salinities $125-300 \%$ that of the ambient seawater creates a localized hypersaline water. The amount of brine discharged into the Gulf is about $33 \mathrm{MCM} /$ day which is very small compared to the total seawater in Gulf, nevertheless salinity buildup in Gulf is observed and is likely to put some of the fragile ecosystems under severe stress. The problem in increasing salinity in Gulf is more complex because of the weak circulation and extremely low freshwater input.

Several studies carried out in Arabian Gulf [6], [11] have suggested salinity increased of the order of $0.06 \mathrm{ppt}$ due to $\mathrm{Al}$ Jubail desalination plant in Saudi Arabia, however the model has considered the ambient salinity as $40 \mathrm{ppt}$, which is lower than measured now. Also the model assumptions are identical for read sea and Arabian Gulf as they are both semi-enclosed seas, joining to the open sea [12]. In recent investigations [13] it is reported that Northern Arabian Gulf is a more complex system and the salinity issues are more serious than observed elsewhere.

\section{MethodologY}

Salinity data was collected by Kuwait Environment Public 
Authority (KEPA) during 1993 and 2003, in the territorial waters of Kuwait that lie along the northwestern margin of the Arabian Gulf (Fig. 1). The bathymetry of northern Arabian/Persian Gulf is shallow with much of the area being $<15$ m deep with a maximum depth of $\sim 50 \mathrm{~m}$. Over the past six years, the average annual precipitation in the area was < $120 \mathrm{~mm}$. The Shatt Al-Arab River and the Third River empty into the northern Gulf supplying it with limited quantities of freshwater. The northern Arabian/Persian Gulf is generally turbid with a sea surface temperature fluctuating between $10^{\circ} \mathrm{C}$ and $35^{\circ} \mathrm{C}$. Fortnightly $\mathrm{pH}$ measurements were carried out at seven locations between January 2007 and June 2013 (Fig. 2). The measurements were carried out using a YSI 556 MPS instrument equipped with a glass sensor with a resolution of 0.01 and an accuracy of $\pm 0.2 \mathrm{pH}$ units. The sensor was calibrated using three National Institute of Standards and Technology (NIST) standard solutions for $\mathrm{pH}$ between measurements [14]. The measurements at all seven sites were completed within an hour using the same instrument. Simultaneous measurements of temperature were also made.

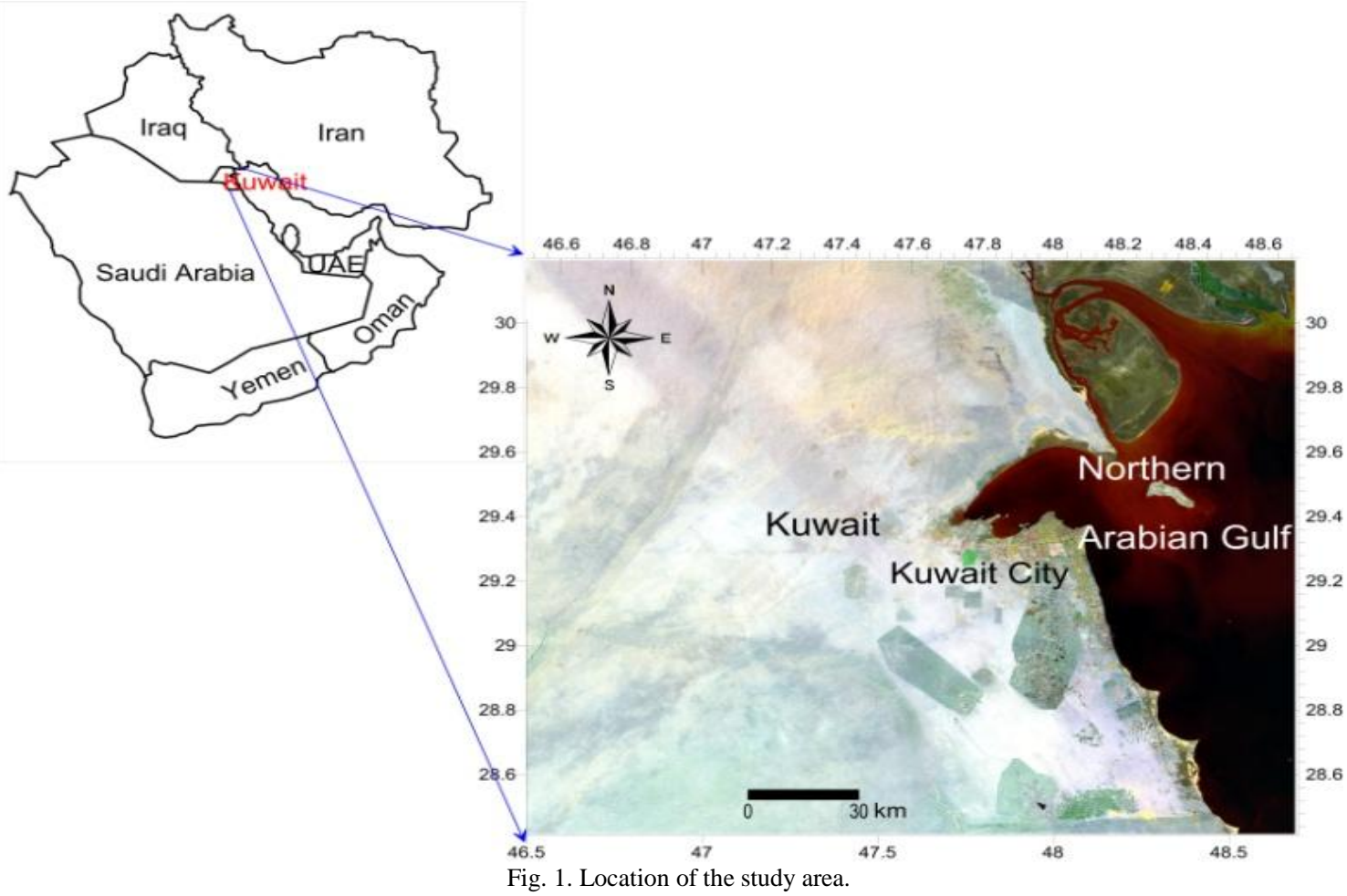

Salinity data have been measured using a Hydrolab Quanta instrument since January 2007 , on a fortnightly basis. The salinity measurements are made one meter below the sea's surface. The instrument was standardized and rinsed with the standard solution before each reading was taken. Triple-point calibration was performed for the instrument, and same instrument was used throughout the measurement at all seven stations.

\section{RESUlTS AND DisCUSSION}

The trend of salinity shows an increase since desalination activities started. An interesting fact that is clearly discernable shows that seasonal salinity variations were significant until 1996, since which time the seasonal variation has been limited to a much smaller range and is clearly incremental, although the corresponding seasonal temperature trend remained almost unchanged between 1993 and 2003.

There has been an upper salinity limit of 42 ppt set by Kuwait Environmental Public Authority (KEPA) for Kuwait's marine waters. There has been a consistent breach of the upper salinity limit set forth by KEPA since 2002, except during November to February at few locations.
In order to further explore the salinity variation KISR has been conducting fortnightly salinity measurements since $1^{\text {st }}$ January 2007 in Northern Arabian Gulf (Fig. 2). These measurements shows salinity exceedences both in summers and winters over the $42 \mathrm{ppt}$ maximum salinity limit set forth by Kuwait Environmental Public Authority. Trend analyses done for the salinity data collected over $6.5 \mathrm{y}$, shows a downward trend that started in June 2012 onwards. This is possibly the response to the acidifying Gulf water [14] which is showing a drop of more than $0.2 \mathrm{pH}$ units in past 5 years (Fig. 3). This drop in $\mathrm{pH}$ is predominantly attributed to $\mathrm{CO}_{2}$ sequestration in the Gulf's waters. The global $\mathrm{CO}_{2}$ global distribution and chemistry has attracted intense scrutiny because of its potential impacts on the environment [15] and human health. The key anthropogenic contributors to increased atmospheric $\mathrm{CO}_{2}$ concentrations are fossil-fuel burning, changes in terrestrial land use and land cover and cement manufacturing [16].

However, the increased salinity acts as a buffering agent for acidifying Gulf waters. The huge desalination capacity installed in the Gulf (Fig. 4) produces more than $33 \mathrm{MCM}$ of concentrated brine each day which is neutralized by the Arabian Gulf's acidifying waters. The bottom sediments of the Persian/Arabian Gulf are predominantly carbonates, which are quite sensitive to $\mathrm{pH}$ variations. The increased 
salinity and alkalinity measurements suggest that the buffering capacity of the Gulf's waters has increased, and the acidification has weakened. This is a positive side effect of the higher salinity. The dissolution of carbonate lags six months to a year from the $\mathrm{pH}$ drop, during which the coral communities are under immense stress. Some corals have been observed to resist this $\mathrm{pH}$ stress by allowing the growth of coralline algae over their hard substrate. The coralline algae grows well in acidifying water, which is believed to be $\mathrm{CO}_{2}$-rich. Thus, the long-term effect of desalination in the Arabian/Persian Gulf is not entirely negative, it is helping to counter the acidification by increasing the buffering capacity of the seawater and stabilizing the $\mathrm{pH}$.

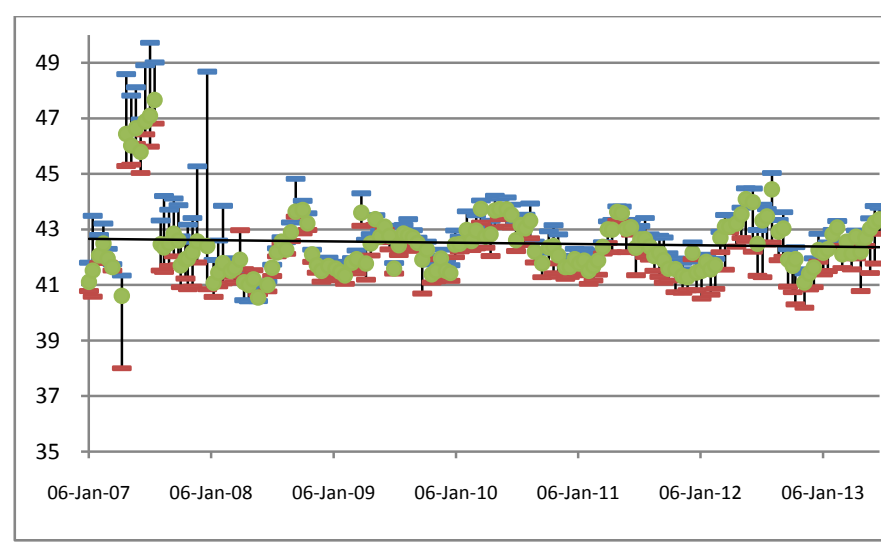

Fig. 2. Salinity measurements in the Northern Arabian Gulf.

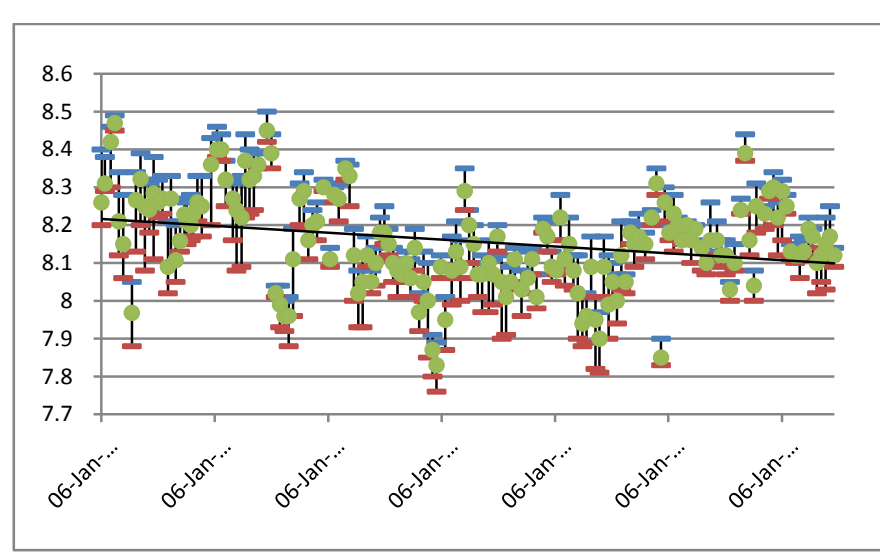

Fig. 3. pH measurements in the Northern Arabian Gulf.

Most of the countries in the Arabian Gulf rely on fossil-fuel to drive their fast-growing economies. Combined they contribute $4.58 \%$ of world's $\mathrm{CO}_{2}$ emissions. Annually, the leading emitter in the region is Iran, which contributes 49.6 million metric tons, followed in decreasing order by Saudi Arabia (40.25 million metric tons), United Arab Emirates (13.56 million metric tons), Iraq (10.01 million metric tons), Kuwait (8.2 million metric tons), Qatar (6.3 million metric tons), Oman (3.73 million metric tons) and Bahrain (2.25million metric tons) [17]. The net $\mathrm{CO}_{2}$ contribution from these oil-producing states is low compared to the top emitters, which include China, the United States, Russia and India; however, their per capita contribution of these oil-producing states is higher.

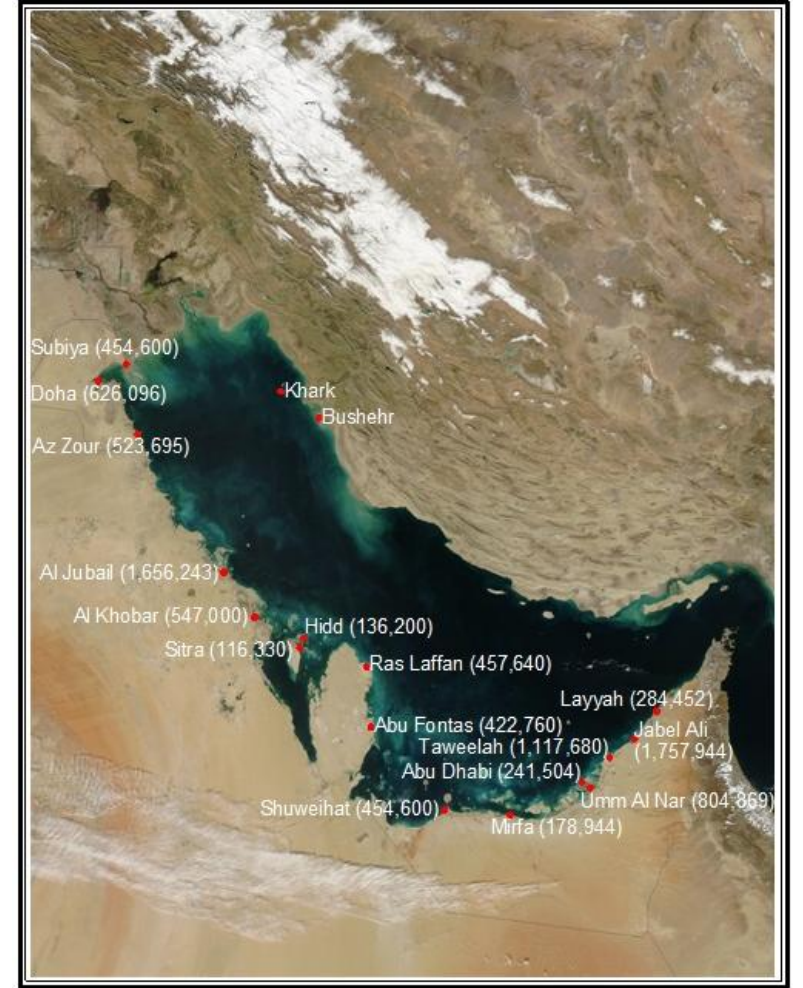

Fig. 4. Power and desalination plants in the Arabian Gulf ( capacities in cubic meter per day ).

The Arabian Gulf is situated in a semi-arid environment characterized by harsh extremes of temperature and sparse vegetation with low atmospheric water vapor through the year. As the photosynthetic removal capacity by terrestrial biota is limited due to the sparse spatial and temporal vegetation cover, it is not inconceivable to expect that a higher fraction of the atmospheric $\mathrm{CO}_{2}$ is likely sequestered in the Arabian Gulf waters leading to acidification of the Gulf.

The land-cover changes brought about by rapid urbanization in countries like Kuwait, Saudi Arabia, Bahrain, Qatar and the United Arab Emirates have further shrunk the vegetated area in these countries, reducing the already limited potential of $\mathrm{CO}_{2}$ removal by terrestrial photosynthesis. In recent years, some of these countries have attempted to enhance vegetation by enacting policies to encourage the planting of trees and demarcation of areas as national nature reserves. In recent years, these policies have led to an improvement in the vegetation index in countries like Kuwait [18]. However, this increased vegetation is often seasonal, as the harsh summers kill off many species. Consequently, terrestrial $\mathrm{CO}_{2}$ sequestration is also seasonal and not an efficient sink for atmospheric $\mathrm{CO}_{2}$. The most probable scenario for $\mathrm{CO}_{2}$ sequestration in the region is oceanic sequestration in the Arabian Gulf, the main water body in the region. Marine ecosystems, however, are sensitive to $\mathrm{CO}_{2}$ enrichment. The carbonate chemistry in the marine environment is also influenced by carbon-dioxide-mediated acidification. The marine carbonate systems effectively respond to the changes in atmospheric $\mathrm{CO}_{2}$. However, their response is time-lagged, usually less than a year [19].

The salinity buildup due to desalination activity is increasing the buffering capacity of seawater to respond to the acidification. Since June 2012 it is observed that the $\mathrm{pH}$ is 
not dropping and the salinity increase has also stopped. The carbonates are dissolved and regulate the $\mathrm{pH}$ in the process the strontium that co-precipitates with calcium is also released, leading in increased strontium concentration in Gulf water [20].

\section{CONCLUSION}

This study helped generate reliable baseline data on the $\mathrm{pH}$ and salinity in the Persian/Arabian Gulf. The time trend produced shows that the initial affect of desalination has led to increased salinity, but the acidifying waters of the Gulf have utilized this increased salinity to buffer the $\mathrm{pH}$ effect. The observed time lag of six months to a year might be critical for coral communities in the Gulf.

\section{ACKNOWLEDGMENT}

The author is thankful to La'al Al-Kuwait and the International Atomic Energy Agency for funding Coordinated Research Project K41012 - Ocean Acidification and the Economic Impact on Fisheries and Coastal Society, under which some of the data used were generated. The author is also thankful to the Kuwait Institute for Scientific Research for providing all of the facilities needed and for supporting this research. Thanks are due to Ms. Marquette Lowther for editing the manuscript and useful suggestions.

\section{REFERENCES}

[1] S. U. Din, A. Al Dousari, and A.N. Al Ghadban, "Sustainable Fresh Water Resources Management in Northern Kuwait - A Remote Sensing View From Raudatain Basin," Int. Jour. Appl. Earth Obs. And Geoinfo., vol. 9, pp. 21 - 31, 2007.

[2] S. Lattemann and T. Hopner, "Environmental impact and impact assessment of seawater desalination," Desalination, vol. 220, issue 1-3, pp. 1 - 15, March 2008.

[3] IDA, IDA Worldwide Desalting Plant Inventory, No. 19 in MS Excel Format, Media Analytics Ltd., Oxford, UK, 2006.

[4] S. Uddin, A.N. Al-Ghadban, B. Gevao, D. Al-Shamroukh, and A. Al-Khabbaz, "Estimation of suspended particulate matter in gulf using MODIS data," Aquatic Ecosystem Health and Management, vol. 15, supplement 1, pp. 41 - 44, doi: 10.1080/14634988.2012.668114.

[5] A. N. Al-Ghadban, S. Uddin, M. U. Beg, A. M. Al-Dousari, B. Gevao, and F. Al-Yamani, "Ecological consequences of river manipulations and drainage of Mesopotamian marshes on the Arabian Gulf ecosystem: investigations on changes in sedimentology and environmental quality, with special reference to Kuwait Bay," final report No. KISR 9362 (EM013C), 2008.

[6] H. H. Al Barwani and A. Purnama, "Evaluating the effect of producing desalinated seawater on hypersaline Arabian Gulf," European Journal of Scientific Research, vol. 22, pp. 279 - 285, 2008.

[7] M. Abdul Jawad and M. Al Tabtabaei, "Impact of current power generation and water desalination on Kuwait marine environment," in
Proc. of DA World Congress on Desalination and Water Reuse, San Diego, 1999, vol. 3, pp. $231-240$.

[8] T. Hopner and S. Lattemann, "Chemical impacts from seawater desalination plants - a case study of northern Rea sea," Desalination, vol. 152, issue 1-3, pp. 133 - 140, February, 2002.

[9] H. Khordagui, Environmental Impacts of Power - Desalination on Gulf Marine Ecosystem, In Khan et al. (Eds.), The Gulf Ecosystem: Health and Sustainability, Leiden: Backhuys Publisher, 2002, pp. 173 $-191$.

[10] S. Lattemann and T. Hopner, Seawater Desalination : Impact of Brine and Chemical Discharge on Marine Environment, Balaban Desalination Publication 2003.

[11] A. Purnama, H. H. Al Barwani, and R. Smith, "Calculating the environmental cost of seawater desalination in the Arabian marginal seas," Desalination, vol. 185, pp. 79 - 86, November 2005.

[12] R. Smith, "Long-term dispersion of contaminants in small estuaries," $J$. Fluid Mech., vol. 82, pp. 129-146, August 1977.

[13] S. Uddin, A.N. Al-Ghadban, and A. Khabbaz, "Localized hypersaline waters in Arabian Gulf from desalination activity - an example from South Kuwait.," Environmental Monitoring and Assessment, vol. 181, issue 1-4, pp. 587-594, October 2011.

[14] S. Uddin, B. Gevao, A.N. Al-Ghadban, M. Nithyandan, and D. Al-Shamroukh, "Acidification in Arabian Gulf - insights from $\mathrm{pH}$ and temperature measurements," Journal of Environmental Monitoring, vol. 14, issue 5, pp. 1479-1482, 2012, doi: 10.1039/C2EM10867D.

[15] K. Caldeira, and M. E. Wickett, "Ocean model predictions of chemistry changes from carbon dioxide emissions to the atmosphere and oceans," Journal Geophysical Research, vol. 110(C09S04), 2005.

[16] B. Bates, Z. W. Kundzewicz, S. Wu, and J. Palutikof, Climate Change and Water, IPCC Secretariat, Geneva, 2008.

[17] T. A.Boden, G. Marland, and R. J. Andres. (2013, June 30). Global, Regional and National Fossil-Fuel $\mathrm{CO}_{2}$ Emissions, Carbon Doixide Information Analysis Center, Oak Ridge National Laboratory. [Online]. http://cdiac.ornl.gov/trends/emis/overview_2007.html.

[18] S. Uddin, A. N. Al Ghadban, A. Al Dousari, M. Al Murad, and D. A Shamroukh, "A remote sensing classification for landcover changes and micro-climate in Kuwait," International Journal of Sustainable Development \& Planning, vol. 5, no. 4, pp. 367-377, $2010 \mathrm{~b}$.

[19] R. E. Zeebe and D. A. Wolf-Gladrow, $\mathrm{CO}_{2}$ in Seawater: Equilibrium, Kinetics, Isotopes, Amestradam, Elsevier, 2001.

[20] S. Uddin, A. N. Al-Ghadban, M. Behnahani. (2013, July 19). Baseline concentration of strontium and ${ }^{90} \mathrm{Sr}$ in seawater from the northern Gulf. Marine Pollution Bulletin. [Online]. Available: http://dx.doi.org/10.1016/j.marpolbul.2013.06.042.

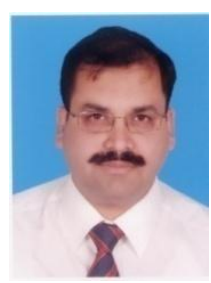

Saif Uddin is a research scientist at Kuwait Institute for Scientific Research. He did his Ph.D. in Remote Sensing, over past two decades he is working on environmental issues in the Gulf. His current interest is radioecology and climate change. He has been looking at the contaminant transport due to acidification and mobilization in coastal waters. He has published several papers in International Peer reviewed journals on these aspects. Dr. Saif has led over 30 projects on environmental issues, the most recent ones include the Ocean Acidification Project, funded by International Atomic Energy Agency in which he serves as Principal Investigator. 